Article

\title{
A Comparison of the Effects of Young-Child Formulas and Cow's Milk on Nutrient Intakes in Polish Children Aged 13-24 Months
}

\author{
Malgorzata Kostecka ${ }^{1, *(D)}$, Izabella Jackowska ${ }^{1}$ and Julianna Kostecka ${ }^{2}$ \\ 1 Faculty of Food Science and Biotechnology, University of Life Sciences in Lublin, Akademicka 15, \\ 20-950 Lublin, Poland; izabella.jackowska@up.lublin.pl \\ 2 Faculty of Medicine, Medical University of Lublin, Chodźki 19, 20-093 Lublin, Poland; \\ kostecka.julianna@gmail.com \\ * Correspondence: kostecka.malgorzatam@gmail.com; Tel.: +48-814-456-846
}

check for updates

Citation: Kostecka, M.; Jackowska, I.; Kostecka, J. A Comparison of the Effects of Young-Child Formulas and Cow's Milk on Nutrient Intakes in Polish Children Aged 13-24 Months. Nutrients 2021, 13, 2511. https: / / doi.org/10.3390/nu13082511

Academic Editor: Isabelle Luron

Received: 28 April 2021

Accepted: 22 July 2021

Published: 23 July 2021

Publisher's Note: MDPI stays neutral with regard to jurisdictional claims in published maps and institutional affiliations.

Copyright: (c) 2021 by the authors Licensee MDPI, Basel, Switzerland. This article is an open access article distributed under the terms and conditions of the Creative Commons Attribution (CC BY) license (https:// creativecommons.org/licenses/by/ $4.0 /)$.

\begin{abstract}
Adequately balanced daily food rations that provide the body with sufficient amounts of energy and nutrients, including minerals, are particularly important in early childhood when rapid physical, intellectual and motor development takes place. Cow's milk (CM) and young-child formulas (YCFs) are introduced to a child's diet past the first year of age. The main aim of the present study was to perform a qualitative and a quantitative analysis of daily food rations of young children based on the recommendations of the daily food ration model. An attempt was also made to determine whether the type of consumed milk (YCF or CM) adequately meets young children's energy demands and contributes to the incorporation of different food groups into a balanced and healthy diet for children aged 13-24 months. A total of 714 parents between October 2019 and March 2020 filled out a food frequency questionnaire. In the second stage of the study, the parents participated in a dietary recall and were asked to keep diaries of all meals and foods consumed by children over a period of three days. The mean daily intake of CM/YCF and fermented milks was determined at $360 \mathrm{~mL} \pm 128 \mathrm{~mL}$, and it accounted for $55.4 \%$ of the guideline values. Flavored dairy products were consumed more frequently than fermented milks without added sugar or flavoring (94 \pm 17 g vs. $56 \pm 26$ g, $p<0.05$ ). Diets incorporating CM were significantly more abundant in protein than YCF diets (29.3 g vs. $21.9 \mathrm{~g} ; p<0.01)$. Liquid intake was somewhat higher in children fed YCFs $(1280.8 \mathrm{~mL}$ vs. 1120.1; $p<0.05)$, mainly due to the higher consumption of fruit juice, nectars and sweetened hot beverages $(246 \pm 35 \mathrm{~mL}$ in the YCF group vs. $201 \pm 56 \mathrm{~mL}$ in the CM group; $p<0.05)$. Children fed YCF consumed significantly larger amounts of sweetened beverages such as tea sweetened with sugar or honey, sweetened hot chocolate or instant teas $(\mathrm{OR}=2.54 ; \mathrm{Cl}$ : $1.32-3.26$; $p<0.001$ ), than children receiving CM. This group was also characterized by higher consumption of sweetened dairy products, mainly cream cheese desserts, fruit yogurt and yogurt with cereal $(\mathrm{OR}=1.87 ; \mathrm{Cl}: 1.36-2.54 ; p<0.01)$, as well as a lower daily intake of plain fermented milks $(\mathrm{OR}=0.56$; Cl: $0.21-0.79 ; p<0.001)$. The daily food intake and the quality of the diets administered to children aged 13-24 months were evaluated and compared with the model food ration. It was found that milk type influenced children's eating habits and preference for sweet-tasting foods. The study also demonstrated that Polish parents and caregivers only have limited knowledge of nutritional guidelines for toddlers.
\end{abstract}

Keywords: young-child formula; cow's milk; nutrient intake; food ration model; children

\section{Introduction}

Adequately balanced daily food rations that provide the body with sufficient amounts of energy and nutrients, including minerals, are particularly important in early childhood when rapid physical, intellectual and motor development takes place [1]. Cow's milk (CM) and young-child formulas (YCFs), also referred to as follow-up formulas [2] or growing-up 
milk (GUM) [3], are introduced to a child's diet past the first year of age. The term "youngchild formula" has been recommended by the European Food Safety Authority (EFSA) because it most accurately describes the age group for which it is intended (1 to 3 years). Not all YCFs contain animal protein, which is why "formula" is preferred over "milk". The term "growing-up" is not recommended because it implies that the formula exerts a specific influence on growth. In an attempt to standardize the applicable terminology, the Committee on Nutrition ( $\mathrm{CoN}$ ) of the European Society for Pediatric Gastroenterology, Hepatology and Nutrition (ESPGHAN) has also recommended "young-child formula" as the most appropriate term [4]. Young-child formulas have a highly varied composition that is not legally regulated, and they may be abundant in protein, carbohydrates as well as large amounts of added sugar in the form of sucrose. According to ESPGHAN guidelines, the protein content of YCFs should approximate the lower threshold value. Research has demonstrated that YCFs increase the intake of vitamin D, iron and n-3 PUFAs. However, these nutrients can be also supplied with unprocessed and/or fortified foods. Based on the existing evidence, ESPGHAN has concluded that there are no grounds for routinely administering YCFs to children aged 1 to 3 years, but YCFs can be a useful strategy to compensate for nutritional deficiencies in children's diets [2,4,5].

Cow's milk is widely consumed by young children in some countries, including Mexico and the United States. In Mexico, more than $86 \%$ of 1- to 3-year-olds consume milk daily [6], and $10 \%-13 \%$ of their daily energy intake comes from milk [7]. In turn, only $4 \%-5 \%$ of the daily energy intake of Chinese children comes from CM, and this product is rarely incorporated in child diets, in particular in the diets of children aged 1 to 2 years [8,9].

Several studies have been conducted to compare the nutrient intakes of children consuming YCFs and CM [10-12]. A report from Germany described the similarities and differences between the contribution of $200 \mathrm{~mL}$ of YCF and $200 \mathrm{~mL}$ of CM (1.5\% fat) to the recommended intakes of energy and macro- and micronutrients [13]. However, energy and nutrient intakes during infants' transition from milk to solid foods have been rarely described comprehensively in the literature [14,15], and there is also a general scarcity of recent studies for the population of Polish toddlers [16].

The daily food ration model for young children developed by Weker et al. [17] is based on Polish norms. The model supports meal planning based on a child's specific energy and nutrient requirements, and it covers six groups of food products.

The main aim of the present study was to perform a qualitative and a quantitative analysis of daily food rations of young children based on the recommendations of the daily food ration model. An attempt was also made to determine whether the type of consumed milk (YCF or CM) adequately meets young children's energy demands and contributes to the incorporation of different food groups into a balanced and healthy diet for children aged 13-24 months.

\section{Methods}

\subsection{Study Sample}

The parents of children aged 13-24 months who had introduced CM to their children's diets at one year of age or continued to administer modified milk past the first birthday were invited to participate in the study. The exclusion criteria were allergy or the risk of allergy (which would require the use of extensively hydrolyzed formulas or amino acid formulas) and other metabolic diseases that require specialist foods. All of the evaluated children were full-term babies with birth weights higher than $2500 \mathrm{~g}$. None of the children was breast-fed at the time of the study.

\subsection{Data Acquisition}

The study was conducted in two stages, but not all parents who participated in the first stage took part in the second stage of the research.

A total of 714 parents whose children were patients of pediatric clinics in Lublin, Kraśnik and Rzeszów in southeastern Poland between October 2019 and March 2020 
consented to participate in the study. In the first stage, the participants filled out a food frequency questionnaire designed based on a validated KomPAN questionnaire [18,19]. During the first meeting, the parents were asked to complete a paper questionnaire containing 25 questions on the frequency of consumption of various food groups, serving size and daily intake of $\mathrm{CM}$ or modified milk, formula brand incorporated in the diet, factors influencing the parents' choice of formula, dietary supplements and fortified foods, as well as basic information about the child's age, body weight and height. A total of 592 correctly completed questionnaires were returned. In the second stage of the study, the parents participated in a dietary recall and were asked to keep diaries of all meals and foods consumed by children over a period of three days. A dedicated form was provided for the purpose, and food dairies were to be completed in the following week. A researcher/student/nurse instructed the participants on how to keep the diary and answered the parents' questions. The parents were asked to record all meals and foods consumed by the child over a period of three non-consecutive days, including Saturday or Sunday. Caregivers were instructed to note the time of each meal, the weight (or volume) of all ingested foods and to accurately describe all food products (including brands), food preparation methods and detailed recipes for all foods prepared at home. Serving size was determined with the use of household measures and utensils (slice, spoon, cup, etc.) and based on photographs of food products and dishes that were presented to the parents during the questionnaire completion.

Food diaries were filled out correctly by 486 parents, and they were divided into three groups:

Group 1-YCF group comprising 178 children who were fed modified milk with a minimum daily intake of $250 \mathrm{~mL}$;

Group 2-CM group comprising 156 children who were fed CM past the age of 12 months with a minimum daily intake of $250 \mathrm{~mL}$, but did not receive YCF or dairy products based on YCF;

Group 3-mixed group of 152 children who were fed both CM and modified milk intended for children aged 1-3 years.

\subsection{Analysis of Food Dairies}

The results of the three-day dietary recall were processed in the Dieta 6 program developed by the Independent Unit of Nutritional Epidemiology and Recommended Dietary Intakes of the National Food and Nutrition Institute in Warsaw based on Polish norms $[20,21]$. The program lists the composition of around 3000 foodstuffs that are widely used for culinary purposes in Polish households, as well as commercial food products for infants and young children (under 3 years of age) available on the Polish market. The composition of less than 12 homemade foods could not be determined, and it was inferred based on similar products. The composition of all baby foods was stated on the nutrition facts label. Energy and nutrient intakes were calculated for each child based on the total food intake during the three-day dietary recall. In addition to total energy intake, the following nutrients were also considered in the analysis: proteins; lipids (with a division into saturated, monounsaturated and polyunsaturated fatty acids); total carbohydrates, including sucrose and lactose (excluding fiber); minerals $\mathrm{Na}, \mathrm{K}, \mathrm{I}, \mathrm{Ca}, \mathrm{P}, \mathrm{Mg}$, Zn and Fe; water-soluble vitamins B1, B2, B6, B12, C and folates; and fat-soluble vitamins E and D (only vitamins occurring naturally in foods) and total vitamin A. In Poland, children aged 1 to 2 years are frequently prescribed vitamin $\mathrm{D}$ and multivitamin supplements. These supplementary intakes were not taken into account in the current study because they are not used regularly throughout the year and are not recommended by pediatricians. 


\subsection{Statistical Analysis}

The mean intake of each nutrient in each group was calculated. The mean intake of each nutrient in each group was compared against the dietary guidelines for $\mathrm{CM}$ and YCF in the independent $t$-test (parametric data) and the non-parametric Kruskal-Wallis test. Mean nutrient intakes were compared between the CM group and the mixed group, and between the YCF group and the mixed group in Dunn's post hoc test.

Adequate intake (AI) values were applied to nutrients without established recommended daily allowance (RDA) cut-offs, including vitamins $\mathrm{D}$ and $\mathrm{E}$. The RDA values for protein, calcium, phosphorus, magnesium, iron, selenium, zinc, copper, thiamin, riboflavin, vitamins B6 and B12, folate and vitamin $\mathrm{C}$ and $\mathrm{AI}$ values for sodium and potassium were determined based on Polish Dietary Guidelines (National Food and Nutrition Institute, 2012). In an analysis of macronutrients (excluding protein and carbohydrates for which RDA values are available), the energy intake from fat was determined based on the acceptable macronutrient distribution ranges (AMDR). The recommended fiber intake was established based on AI values.

The normality of distribution of continuous variables was assessed in the ShapiroWilk test. For continuous variables, data were presented as means with a $95 \%$ confidence interval (95\% CI). Three groups of respondents were analyzed as follows: (i) CM group, (ii) YCF group and (iii) mixed group. The significance of odds ratios (ORs) was assessed with Wald's statistics.

Data were processed in the Statistica program (version 12.0 PL, StatSoft Inc., Tulsa, OK, USA, StatSoft, Krakow, Poland) at three levels of significance ( $p): p<0.05,<0.01$ and $<0.001$.

\section{Results}

\subsection{Analysis of Daily Food Rations}

The estimated number of servings and serving size of different food products in the daily rations of the evaluated children differed from the guideline values (Table 1).

Table 1. The estimated number of servings and serving size of different food products in the daily rations of children aged 13-24 months and guideline values [17].

\begin{tabular}{|c|c|c|c|c|}
\hline & \multicolumn{2}{|r|}{ Guidelines } & \multicolumn{2}{|r|}{ Dietary Recalls } \\
\hline & No. of Servings & Serving Size & Mean No. of Servings & Serving Size \\
\hline I. Protein foods & 4-5 Servings & & 5-6 Servings & \\
\hline Dairy foods & 3 servings & $\begin{array}{l}1 \text { cup of milk ( } 2 \%-3.2 \% \text { fat } \\
\text { content), } \\
1 \text { cup of modified milk (for } \\
\text { children aged } 1-3 \text { years), } \\
1 / 2 \text { cup of yogurt, kefir or } 2 \\
\text { teaspoons of tvorog, cottage } \\
\text { cheese or } 1 \text { teaspoon of grated } \\
\text { yellow cheese }\end{array}$ & $2-3$ servings & $\begin{array}{ll}\text { - } & 1 \text { cup of milk ( } 2 \%-3.2 \% \text { fat }), \\
-\quad & 1 \text { cup of modified milk (for } \\
\text { children aged } 1-3 \text { years), } \\
\text { - } \quad 1 \text { small tub of yogurt or cream } \\
\text { cheese dessert, } \\
\begin{array}{l}1 \text { teaspoon of grated yellow } \\
\text { cheese or a slice of tvorog }\end{array}\end{array}$ \\
\hline $\begin{array}{l}\text { Other protein } \\
\text { foods }\end{array}$ & $1-2$ servings & $\begin{array}{l}\text { - } \quad 1 / 2 \text { egg or } 1 \text { slice of cold cuts } \\
\text { made of lean meat, } \\
\text { - } 1 \text { serving of meat or fish }\end{array}$ & 3 servings & $\begin{array}{ll}- & 1 \mathrm{egg} / 2 \text { slices of ham, } \\
- & 1 \text { sausage, } \\
- & 1 \text { serving of roast meat or fish }\end{array}$ \\
\hline II. Cereal products & 5 servings & $\begin{array}{l}\text { - } \quad 1 / 2 \text { wheat roll or } 1 \text { slice of } \\
\text { wheat bread, } \\
\text { - } 1 / 2 \text { whole wheat roll or } 1 \text { slice } \\
\text { of whole wheat bread, } \\
\text { - } 1 / 2 \text { cup of cereal, } \\
\text { - } \quad 2 \text { tablespoons of cooked } \\
\text { groats, pasta or rice, } \\
\text { crepe, pancake or cake }\end{array}$ & 4 servings & $\begin{array}{l}1 \text { wheat roll or } 1 \text { slice of wheat } \\
\text { bread, } \\
\text { - } \quad 1 / 2-1 \text { cup of breakfast cereal, } \\
\text { - } \quad 2-3 \text { tablespoons of cooked } \\
\text { groats, pasta or rice, } \\
\text { crepe, pancake or cake }\end{array}$ \\
\hline
\end{tabular}


Table 1. Cont.

\begin{tabular}{|c|c|c|c|c|c|}
\hline & \multicolumn{2}{|r|}{ Guidelines } & \multicolumn{3}{|c|}{ Dietary Recalls } \\
\hline & No. of Servings & Serving Size & Mean No. of Servings & & Serving Size \\
\hline III. Vegetables & 5 servings & 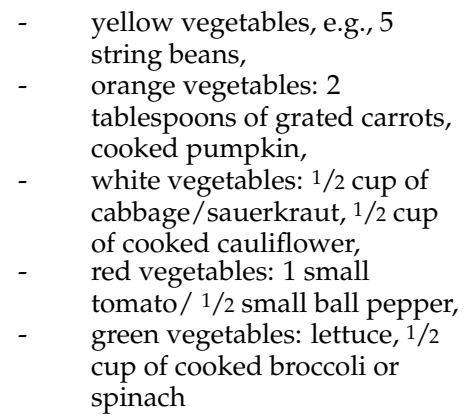 & $2-3$ servings & - & $\begin{array}{l}\text { orange vegetables: } 2-3 \\
\text { tablespoons of grated carrots, } \\
\text { red vegetables: } 1 \text { small } \\
\text { tomato/ } 1 \text { cooked beet } / 2 \\
\text { tablespoons of blanched red } \\
\text { cabbage, } \\
\text { green vegetables: lettuce, } \\
\text { chives, } 2-3 \text { tablespoons of } \\
\text { cooked broccoli or courgette }\end{array}$ \\
\hline IV. Fruit & 4 servings & $\begin{array}{ll}\text { - } & \text { yellow and orange fruit: } 1 \\
\text { apple, } 2-3 \text { apricots, } 1 / 2 \text { banana } \\
\text { or orange, } \\
\text { - } \quad \text { purple fruit: } 1 / 2 \text { cup of } \\
\text { currants / berries, } \\
\text { red fruit: } 1 / 2 \text { cup of raspberries } \\
\text { or strawberries, } \\
\text { - } 1 / 2 \text { cup of freshly squeezed } \\
\text { fruit juice }\end{array}$ & $2-3$ servings & - & $\begin{array}{l}\text { yellow and orange fruit: } 1 \\
\text { apple, } 1 / 2 \text { banana or orange, or } \\
\text { a small tangerine, } \\
1-11 / 2 \text { cups of bottled or } \\
\text { freshly squeezed fruit juice }\end{array}$ \\
\hline V. Fat & $1-2$ servings & $\begin{array}{ll}\text { - } & 1 \text { tablespoon of olive oil or } \\
\text { rapeseed oil } \\
\text { - } \quad 1 \text { teaspoon of butter }\end{array}$ & $2-3$ servings & - & $\begin{array}{l}1-2 \text { teaspoons of } \\
\text { butter/margarine } \\
\text { teaspoon of rapeseed oil }\end{array}$ \\
\hline
\end{tabular}

The evaluated children consumed more protein foods, in particular meat, cold cuts and processed meat, which increased the percentage of protein foods in the daily ration (Table 2). The consumption of dairy products was below the recommended levels. The mean daily intake of CM/YCF and fermented milks was determined at $360 \mathrm{~mL} \pm 128 \mathrm{~mL}$, and it accounted for $55.4 \%$ of the guideline values. Flavored dairy products were consumed more frequently than fermented milks without added sugar or flavoring ( $94 \pm 17 \mathrm{~g}$ vs. $56 \pm 26 \mathrm{~g}, p<0.05)$. Children's diets were more abundant in wheat and whole wheat (graham) bread than whole grain bread $(p<0.05)$, and highly processed breakfast cereals with added sugar were consumed more frequently than oatmeal or buckwheat groats $(27 \pm 12 \mathrm{~g}$ vs $10 \pm 10 \mathrm{~g} ; p<0.05)$. The analyzed diets were deficient in vegetables and fruit, and children consumed 2-3 servings of vegetables and fruit daily on average. Most diets were monotonous, and they featured mostly orange, red and green vegetables, whose daily consumption reached $140 \pm 59 \mathrm{~g}$ vs. the recommended amount of $200 \mathrm{~g}$. Carrots, tomatoes and lettuce were most frequently consumed, whereas cruciferous vegetables, including cabbage and cauliflower, as well as pumpkin, were the least popular. Daily consumption of fruit, mostly yellow and orange fruit (apples and bananas), accounted for $86 \%$ of the recommended daily intake. Average juice consumption was determined at $220 \pm 29 \mathrm{~mL}$, and it exceeded the recommended daily amount of $125 \mathrm{~mL}$. The consumption of freshly squeezed fruit juice, pasteurized fruit juice, bottled fruit nectars and juice was too excessive $(135 \pm 15 \mathrm{~mL}$ vs. $175 \pm 35 \mathrm{~mL}$ vs. $200 \pm 25 \mathrm{~mL})$. The consumption of sugar and sweets differed across the analyzed diets $(p<0.05)$. In the model food ration, daily sugar intake is limited to $20 \mathrm{~g}$. Only $24 \%$ of the children consumed $20-24 \mathrm{~g}$ of sugar daily $(100 \%-115 \%$ of the guideline values). In $11 \%$ of the cases, daily sugar intake was determined at $16-19 \mathrm{~g}$ and was below guideline values. However, in $65 \%$ of the examined diets, daily sugar intake exceeded the guideline levels 2 - to 3 -fold. These children consumed $53 \pm 9 \mathrm{~g}$ sugar on average, mostly from sweetened dairy products such as cream cheese desserts, as well as candy bars, chocolate, gummy sweets and sweetened juice. 
Table 2. The recommended daily ration for children aged 13-24 months and the mean daily intake of various food products in the analyzed food diaries.

\begin{tabular}{|c|c|c|c|c|}
\hline Product Groups & Unit & $\begin{array}{l}\text { Daily Ration Based on } \\
\text { Guidelines } \\
\text { Model Food Ration (2013) }\end{array}$ & $\begin{array}{l}\text { Mean Daily Ration in } \\
\text { Food Diaries }\end{array}$ & $\begin{array}{l}\text { \% of the Model Food } \\
\text { Ration (2013) }\end{array}$ \\
\hline \multicolumn{5}{|l|}{ Cereal products } \\
\hline Bread & $\mathrm{g}$ & 20 & 25 & 125 \\
\hline Flour, pasta & $\mathrm{g}$ & 25 & 30 & 120 \\
\hline Groats, rice, breakfast cereal & $\mathrm{g}$ & 30 & 42 & 140 \\
\hline Potatoes & $\mathrm{g}$ & $80-100$ & 50 & $50-62.5$ \\
\hline Vegetables and fruit & $\mathrm{g}$ & 450 & 355 & 78.9 \\
\hline Vegetables & $\mathrm{g}$ & 200 & 140 & 70 \\
\hline Fruit & $\mathrm{g}$ & 250 & 215 & 86 \\
\hline Milk and dairy products & $\mathrm{g}$ & & & \\
\hline $\begin{array}{l}\text { Milk, modified milk and } \\
\text { fermented milks }\end{array}$ & $\mathrm{g}$ & 650 & 360 & 55.4 \\
\hline Tvorog and cottage cheese & $\mathrm{g}$ & $10-15$ & 5 & $33.3-50$ \\
\hline Rennet cheese & $\mathrm{g}$ & 2 & 10 & 500 \\
\hline Meat, cold cuts and fish & $\mathrm{g}$ & & & \\
\hline Red meat and poultry & $\mathrm{g}$ & 15 & 20 & 133.3 \\
\hline Cold cuts & $\mathrm{g}$ & 5 & 40 & 800 \\
\hline Fish & $\mathrm{g}$ & 10 & 5 & 50 \\
\hline Eggs & $\mathrm{g} /$ number & $1 / 2$ egg & $1 / 2$ egg & 100 \\
\hline Fat & $\mathrm{g}$ & 16 & 22 & 137.5 \\
\hline Animal fat: butter and cream & $\mathrm{g}$ & 6 & 20 & 333.3 \\
\hline Vegetable fat: oil & $\mathrm{g}$ & 10 & 2 & 20 \\
\hline Sugar and sweets & $\mathrm{g}$ & 20 & 48 & 240 \\
\hline
\end{tabular}

3.2. The Influence of Young-Child Formulas and Cow's Milk on the Nutritional Value of the Diets of Children Aged 13-24 Months

The nutritional composition of YCFs available on the Polish market (six brands, for children aged 1 year and older) and the average composition of whole $\mathrm{CM}$ are shown in Table 3. The remaining YCFs were characterized by a higher content of saturated fatty acids $(1.33 \mathrm{~g} / 100 \mathrm{~mL})$ that was similar to $\mathrm{CM}$, as well as high sucrose content $(1.2-2.4 \mathrm{~g} / 100 \mathrm{~mL})$.

All YCF brands contained dietary fiber (galacto-oligosaccharides/fructo-oligosaccharides). The greatest differences were observed in the content of iron, vitamins $D$ and $C$ and folic acid, which was very low in (unfortified) $\mathrm{CM}$ and high in YCF. One YCF brand was additionally fortified with calcium $(217 \mathrm{mg} / 100 \mathrm{~mL})$, magnesium $(20 \mathrm{mg} / 100 \mathrm{~mL})$ and iodine $(42 \mu \mathrm{g} / 100 \mathrm{~mL})$, and it was significantly more abundant in iodine than the remaining YCFs, where the average iodine content was determined at $18.03 \pm 6.01 \mu \mathrm{g} / 100 \mathrm{~mL}$.

The mean daily intake of YCF was higher $(283 \mathrm{~mL})$ than the intake of CM $(261 \mathrm{~mL})$, but the difference was not statistically significant. The average nutritional value of YCF diets was significantly $(p<0.05)$ higher than that of CM diets (Table 4$)$. Diets incorporating CM were significantly more abundant in protein than YCF diets $(29.3 \mathrm{~g}$ vs. $21.9 \mathrm{~g} ; p<0.01)$. Cow's milk and natural dairy products were the main sources of dietary protein. Average carbohydrate intake in the analyzed population was similar to that of children fed CM, whereas the consumption of YCF increased the content of carbohydrates, in particular sucrose, in the daily ration $(67.6 \mathrm{~g}$ vs. $33.8 \mathrm{~g} ; p<0.001)$. 
Table 3. Nutritional value of YCFs and whole cow's milk.

\begin{tabular}{|c|c|c|c|}
\hline Nutritional Value per $100 \mathrm{~g}$ of the Product & $\mathrm{YCF}^{1}$ (Min-Max) & SD & Whole Cow's Milk ${ }^{2}$ \\
\hline Energy, kcal & $70(65-86)$ & 3.53 & 61 \\
\hline Fat, $\mathrm{g}$ & $3.05(2.6-4.2)$ & 0.58 & 3.2 \\
\hline Saturated fatty acids, $g$ & $0.94(0.6-1.3)$ & 0.31 & 1.92 \\
\hline Monounsaturated fatty acids, $g$ & $1.37(0.97-1.9)$ & 0.31 & 1.01 \\
\hline Polyunsaturated fatty acids, $g$ & $0.61(0.4-1.0)$ & 0.22 & 0.08 \\
\hline Carbohydrates, $\mathrm{g}$ & $8.68(8.1-9.2)$ & 0.44 & 4.8 \\
\hline Sugar, $g$ & $7.47(6.1-9.0)$ & 1.11 & 4.8 \\
\hline Lactose, $g$ & $6.6(5.4-9.0)$ & 1.49 & 4.6 \\
\hline Sucrose, $\mathrm{g}$ & $0.9(0.0-2.4)$ & 0.86 & 0.2 \\
\hline Fiber, $g$ & $0.66(0.32-1.0)$ & 0.27 & 0 \\
\hline Protein, $\mathrm{g}$ & $1.64(1.0-3.2)$ & 0.78 & 3.3 \\
\hline Sodium, $\mathrm{g}$ & $24.74(13.45-32.0)$ & 13.1 & 44 \\
\hline Vitamin $A, \mu g$ & $61.17(50.0-69.0)$ & 6.88 & 36 \\
\hline Vitamin D, $\mu \mathrm{g}$ & $2.23(1.05-3.2)$ & 0.93 & 0.03 \\
\hline Vitamin E, mg & $0.93(0.8-1.1)$ & 0.12 & 0.10 \\
\hline Vitamin C, mg & $12.61(8.4-15.0)$ & 2.87 & 1.0 \\
\hline Thiamine, mg & $0.05(0.04-0.07)$ & 0.01 & 0.04 \\
\hline Riboflavin, mg & $0.20(0.097-0.3)$ & 0.07 & 0.17 \\
\hline Niacin, mg & $0.58(0.2-1.2)$ & 0.36 & 0.1 \\
\hline Vitamin B6, mg & $0.08(0.06-0.105)$ & 0.02 & 0.05 \\
\hline Folic acid, $\mu \mathrm{g}$ & $11.38(9.0-13.0)$ & 1.36 & 5.0 \\
\hline Vitamin $B 12, \mu \mathrm{g}$ & $0.39(0.2-0.61)$ & 0.16 & 0.4 \\
\hline Calcium, mg & $133.5(83.0-217.0)$ & 44.4 & 118 \\
\hline Iron, $\mathrm{mg}$ & $1.22(0.8-1.7)$ & 0.29 & 0.1 \\
\hline Zinc, mg & $0.7(0.4-0.9)$ & 0.18 & 0.32 \\
\hline Magnesium, mg & $11.66(6.3-20.0)$ & 5.1 & 12 \\
\hline Iodine, $\mu \mathrm{g}$ & $22.03(13.8-42.0)$ & 10.1 & No data \\
\hline
\end{tabular}

${ }^{1}$ based on the nutrition facts labels of six YCFs available on the Polish market. ${ }^{2}$ nutritional value of whole cow's milk according to Polish producers.

Liquid intake was somewhat higher in children fed YCFs $(1280.8 \mathrm{~mL}$ vs. 1120.1; $p<0.05)$, mainly due to the higher consumption of fruit juice, nectars and sweetened hot beverages $(246 \pm 35 \mathrm{~mL}$ in the YCF group vs. $201 \pm 56 \mathrm{~mL}$ in the CM group; $p<0.05)$.

Daily rations were also compared for the content of vitamins and minerals (Table 5). Vitamin A content was elevated in all cases, in particular in the YCF group, where vitamin A intake accounted for $231.5 \%$ of the reference value $(p<0.001)$, which was attributed to the consumption of fortified YCFs, dairy products and carrots. In the CM group, the dietary intake of vitamin $\mathrm{D}$ was very low $(2.11 \mu \mathrm{g}, 42.2 \%$ of $\mathrm{AI}$ values), mainly because $\mathrm{CM}$, unlike YCF, is not fortified with vitamin D.

The intake of water-soluble vitamins was equivalent to $86 \%-124 \%$ of the guideline values in diets containing both CM and YCF. Considerable differences were observed only in vitamin C intake, which reached $217 \%$ of the guideline levels in YCF diets $(p<0.01)$.

The analyzed diets met the children's demand for calcium, iron and iodine. Phosphorus $(166.4 \%$ in the YCF group vs. $134.7 \%$ in the CM group; $p<0.01)$ and sodium $(135.2 \%$ in the YCF group vs. $126.2 \%$ in the CM group; $p<0.05)$ intake was very high. The recommended intake of potassium was exceeded in the YCF group $(148.8 \%$ of the reference value) despite the fact that YCF preparations on the Polish market are less abundant in potassium than CM. 
Table 4. Energy content nutritional value of the evaluated diets of children aged 13-24 months vs. dietary guidelines and expert recommendations.

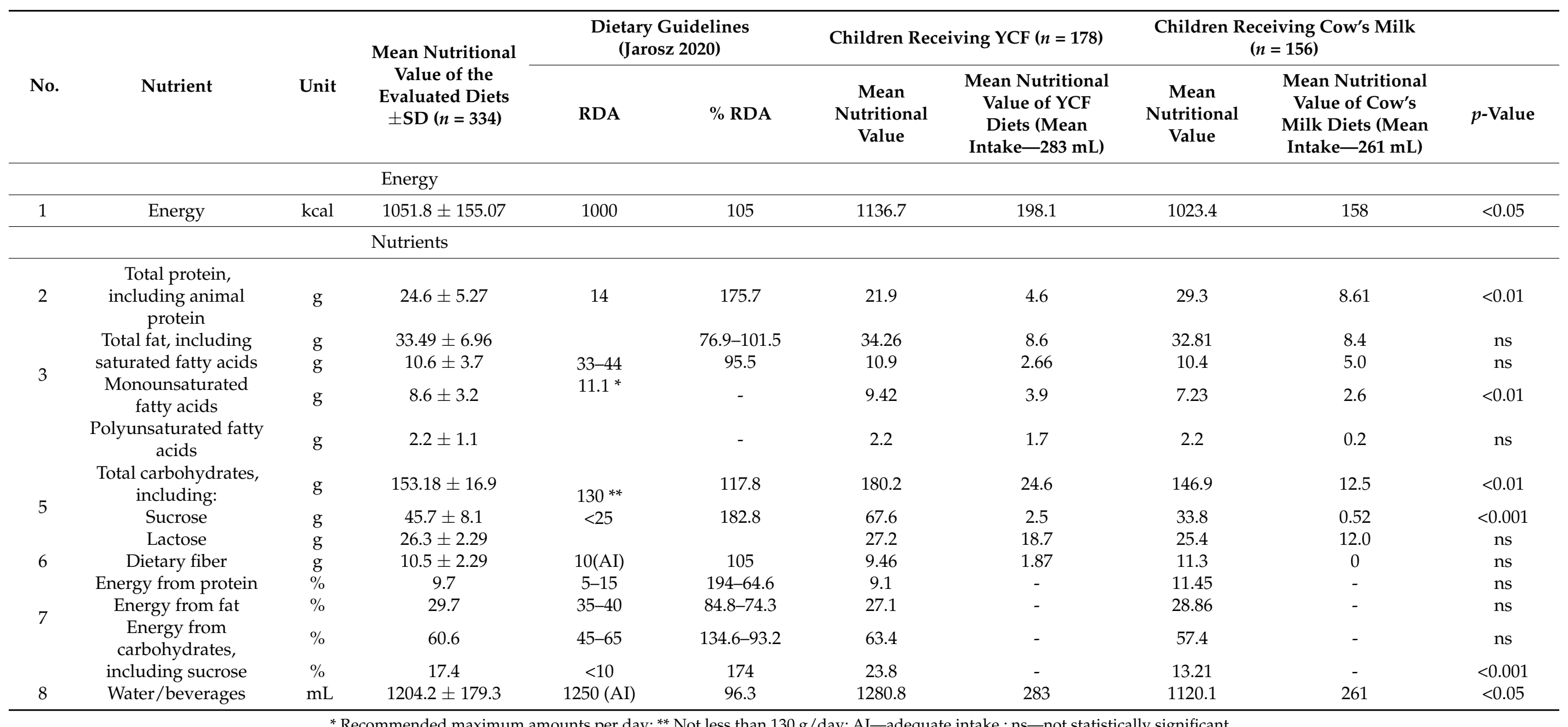


Table 5. Energy and nutritional value of the evaluated diets of children aged 13-24 months vs. dietary guidelines and expert recommendations.

\begin{tabular}{|c|c|c|c|c|c|c|c|c|c|c|}
\hline \multirow[b]{2}{*}{ No. } & \multirow[b]{2}{*}{ Nutrient } & \multirow[b]{2}{*}{ Unit } & \multirow{2}{*}{$\begin{array}{l}\text { Mean Nutritional } \\
\text { Value of the } \\
\text { Evaluated Diets } \\
\pm \text { SD }(n=334)\end{array}$} & \multicolumn{2}{|c|}{$\begin{array}{l}\text { Dietary Guidelines } \\
\text { (Jarosz 2020) }\end{array}$} & \multicolumn{2}{|c|}{ Children Receiving YCF $(n=178)$} & \multicolumn{2}{|c|}{$\begin{array}{l}\text { Children Receiving Cow's Milk } \\
\qquad(n=156)\end{array}$} & \multirow[t]{2}{*}{$p$-Value } \\
\hline & & & & RDA & $\%$ RDA & $\begin{array}{c}\text { Mean } \\
\text { Nutritional } \\
\text { Value }\end{array}$ & $\begin{array}{l}\text { Mean Nutritional } \\
\text { Value of YCF } \\
\text { Diets (Mean } \\
\text { Intake-230 mL) }\end{array}$ & $\begin{array}{c}\text { Mean } \\
\text { Nutritional } \\
\text { Value }\end{array}$ & $\begin{array}{l}\text { Mean Nutritional } \\
\text { Value of Cow's } \\
\text { Milk Diets (Mean } \\
\text { Intake-180 mL) }\end{array}$ & \\
\hline \multicolumn{11}{|c|}{ Fat-soluble vitamins } \\
\hline 1 & Vitamin A & $\mu g$ & $734.7 \pm 175.1$ & 400 & 183.6 & 926.1 & 172.4 & 531.3 & 93.9 & $<0.001$ \\
\hline 2 & Vitamin E & $\mathrm{mg}$ & $6.01 \pm 1.4$ & $6(\mathrm{AI})$ & 100 & 6.1 & 2.63 & 5.84 & 0.26 & ns \\
\hline 3 & Vitamin D & $\mu \mathrm{g}$ & $5.7 \pm 1.7$ & $15(\mathrm{AI})$ & 38 & 9.81 & 6.3 & 2.11 & 0.07 & $<0.001$ \\
\hline \multicolumn{11}{|c|}{ Water-soluble vitamins } \\
\hline 4 & Vitamin B1 & $\mathrm{mg}$ & $0.44 \pm 0.18$ & 0.5 & 88 & 0,47 & 0.14 & 0.42 & 0.1 & ns \\
\hline 5 & Vitamin B2 & $\mathrm{mg}$ & $0.62 \pm 0.16$ & 0.5 & 124 & 0.72 & 0.57 & 0.58 & 0.45 & ns \\
\hline 6 & Foliates & $\mu \mathrm{g}$ & $138.9 \pm 19.4$ & 150 & 92.6 & 136.6 & 26.17 & 140.3 & 13.05 & ns \\
\hline 7 & Vitamin B12 & $\mathrm{mg}$ & $0.9 \pm 0.46$ & 0.9 & 100 & 0.94 & 1.1 & 0.83 & 1.04 & ns \\
\hline 8 & Vitamin C & $\mathrm{mg}$ & $61.5 \pm 36.2$ & 40 & 153.8 & 86.8 & 35.7 & 40.7 & 2.61 & $<0.01$ \\
\hline 10 & Vitamin B6 & $\mathrm{mg}$ & $0.43 \pm 0.17$ & 0,5 & 86 & 0.44 & 0.22 & 0.43 & 0.13 & ns \\
\hline 1 & Calcium (Ca) & $\mathrm{mg}$ & $689.57 \pm 167.1$ & 700 & 98.5 & 714.2 & 377.7 & 663.7 & 310.9 & ns \\
\hline 2 & Phosphorus (P) & $\mathrm{mg}$ & $678 \pm 186.2$ & 460 & 147.4 & 765.4 & 187.8 & 619.8 & 222.9 & $<0.01$ \\
\hline 3 & Magnesium (Mg) & $\mathrm{mg}$ & $62.6 \pm 15.3$ & 80 & 78.3 & 61.7 & 32.9 & 63.8 & 31.3 & ns \\
\hline 4 & Iron $(\mathrm{Fe})$ & $\mathrm{mg}$ & $7.45 \pm 1.9$ & 7 & 106.4 & 7.61 & 3.46 & 7.31 & 0.26 & ns \\
\hline 5 & Zinc (Zn) & $\mathrm{mg}$ & $1.8 \pm 1.2$ & 3 & 60 & 2.43 & 1.98 & 1.4 & 0.84 & $<0.01$ \\
\hline 8 & Iodine (I) & $\mu \mathrm{g}$ & $94.6 \pm 17.3$ & 90 & 105 & 91.6 & 28.7 & 98.3 & 28.6 & ns \\
\hline 9 & Potassium (K) & $\mathrm{mg}$ & $1097.5 \pm 277.1$ & 800(AI) & 137.2 & 1190.2 & 300.2 & 1009.4 & 363.8 & $<0.05$ \\
\hline 10 & Sodium (Na) & $\mathrm{mg}$ & $957.1 \pm 229.9$ & $750(\mathrm{AI})$ & 127.6 & 1014.2 & 70.0 & 946.5 & 114.8 & $<0.05$ \\
\hline
\end{tabular}




\subsection{The Associations between the Type of Consumed Milk and the Composition of the Diets of Children Aged 13-24 Months}

Food diaries and the results of dietary interviews with parents were analyzed to identify products that were most widely consumed by children fed CM and YCFs (Table 6).

Table 6. Odds ratios (95\% confidence interval). The associations between the type of consumed milk, YCF vs. cow's milk, and the composition the diets of children aged 13-24 months.

\begin{tabular}{|c|c|c|c|c|c|c|}
\hline \multirow[b]{2}{*}{ Product } & \multicolumn{3}{|c|}{ YCF Group vs. Mixed Group } & \multicolumn{3}{|c|}{ Cow's Milk Group vs. Mixed Group } \\
\hline & OR & $95 \% \mathrm{CI}$ & ${ }^{*} p$-Value & OR & $95 \% \mathrm{CI}$ & $p$-Value \\
\hline Juice & 1.43 & $0.91-2.24$ & ** & 0.94 & $0.73-1.21$ & ns \\
\hline Sweetened beverages & 2.54 & $1.32-3.26$ & $* * *$ & 0.79 & $0.56-1.08$ & ns \\
\hline Sweet snacks & 0.76 & $0.44-0.94$ & $* *$ & 0.91 & $0.73-1.17$ & ns \\
\hline Sweets & 1.17 & $0.86-1.32$ & ns & 0.97 & $0.79-1.10$ & ns \\
\hline Natural dairy products, plain yogurt & 0.56 & $0.21-0.79$ & $* * *$ & 1.84 & $1.26-2.41$ & $* *$ \\
\hline $\begin{array}{l}\text { Sweetened dairy products, such as } \\
\text { cream cheese dessert }\end{array}$ & 1.87 & $1.36-2.54$ & $* *$ & 0.64 & $0.26-0.89$ & $* * *$ \\
\hline Breakfast cereal & 0.9 & $0.86-1.19$ & ns & 1.28 & $0.79-1.56$ & * \\
\hline Fruit preserves & 1.17 & $0.86-1.32$ & ns & 1.06 & $0.76-1.14$ & ns \\
\hline
\end{tabular}

Statistically significant (Wald's statistics): ${ }^{*} p$ value $<0.05,{ }^{* *} p<0.01,{ }^{* *} p<0.001$, ns-not statistically significant.

Children aged 13-24 months fed YCF consumed significantly larger amounts of sweetened beverages such as tea sweetened with sugar or honey, sweetened hot chocolate or instant teas $(\mathrm{OR}=2.54 ; \mathrm{Cl}: 1.32-3.26 ; p<0.001)$ than children receiving $\mathrm{CM}$. This group was also characterized by higher consumption of sweetened dairy products, mainly cream cheese desserts, fruit yogurt and yogurt with cereal $(\mathrm{OR}=1.87 ; \mathrm{Cl}: 1.36-2.54 ; p<0.01)$, and lower daily intake of plain fermented milks (OR $=0.56 ; \mathrm{Cl}: 0.21-0.79 ; p<0.001)$.

In the group of children fed $\mathrm{CM}$, the consumption of plain fermented milks was significantly higher $(\mathrm{OR}=1.84 ; \mathrm{Cl}: 1.26-2.41 ; p<0.01)$ and the daily intake of sweetened dairy products was lower $(\mathrm{OR}=0.64 ; \mathrm{Cl}: 0.26-0.89 ; p<0.001)$ than in the YCF group. The mean daily intake of plain yogurt was determined at $74 \pm 12 \mathrm{~g}$ in the CM group and at $39 \pm 21 \mathrm{~g}$ in the YCF group. The frequency of consumption and the size of breakfast cereal portions were higher in the YCF group, but the difference was not statistically significant. The daily intake of sweets was also similar in the compared groups. The most popular sweets were chocolate, chocolate-filled milk bars and gummy sweets in the YCF group, and candy bars, ice cream and chocolate and hazelnut spreads in the CM group.

\section{Discussion}

In the present study, the daily food ration of toddlers (aged 13-24 months) was evaluated and compared with the model daily ration, and the influence of CM and YCFs on the mean daily nutrient intake was determined. Dietary behaviors and choices in early childhood play a significant role in healthy growth and development. Despite that, the quality of diets consumed by children younger than 24 months has been rarely analyzed in the literature [22,23].

\subsection{Daily Food Ration}

Based on the guidelines of the World Health Organization (WHO), daily consumption of added sugar should be less than $10 \%$ of total daily energy intake. Based on a limited number of population-wide studies of sugar intake, the WHO also concluded a study that a reduction in the intake of added sugar to below 5\% of total energy intake would decrease the risk of dental caries in children [24]. According to the Scientific Advisory Committee on Nutrition (SACN) in the UK and the American Heart Association (AHA), daily sugar intake should be below $5 \%$ of total energy intake, which implies that children younger than 3 years should consume less than 3 teaspoons of sugar, which is equivalent to $170 \mathrm{~mL}$ of fruit nectar $(81-260 \mathrm{~mL})[25,26]$. In the current study, daily sugar intake was equivalent 
to $135 \%$ (CM group) to $270 \%$ (YCF group) of the reference value, and the main sources of sugar were sweetened beverages, juice and commercially available complementary foods (CACFs). Almost $30.0 \%$ of CACFs (such as fruit juice and concentrates) in Austria, 32.6\% of CACFs in Israel, 37.5\% of CACFs in Hungary and $41.4 \%$ in Bulgaria contained added sugars and sweeteners [27]. In the USA, more than $70.0 \%$ of CACFs for toddlers contained one or more added sugars [28]. In the present study, $72 \%$ of children consumed at least one type of sweets daily. Significantly lower values were noted by Yu et al. (2016), where only $40 \%$ of children aged 21-35 months consumed one type of sweets such as biscuits, honey and chocolate [9]. In some studies, sugar intake was higher among girls than boys [29]. In contrast, Yuan et al. [30] reported that boys consumed more sugar and sweet snacks than girls at the age of 8 months. In the present study, the consumption of sugar and sweets did not differ between the sexes, and similar observations were made by Masztalerz-Kozubek (2020) in a study of Polish children aged 12-36 months [31].

Research conducted in the USA and Brazil demonstrated that the intake of fruit and vegetables was less than adequate among infants and young children [32-35]. Unlike in the present study, the Nestlé Feeding Infants and Toddlers Study (FITS) (2016) revealed that $27 \%$ of 2- to 3-year-olds did not consume the recommended amounts of vegetables [34]. In this study, orange vegetables were most popular, and up to $64 \%$ of the surveyed children consumed 1 portion of these products. In contrast, dark green vegetables were consumed by every fourth child, and red vegetables by every third child. Only $40 \%$ of the evaluated children consumed dark green leafy vegetables, and the consumption of deep yellow vegetables was even lower [9]. In a study by Deming et al. [36], fewer children consumed dark yellow than dark green vegetables. The selection of vegetables in the diet plays a very important role in child nutrition because brightly colored vegetables are more abundant in bioactive components. The content of antioxidants from vegetables and fruits is great importance for health, and diet plays a crucial role in the regulation of chronic inflammation [37,38].

Daily fruit intake was below the recommended level of 4 servings, and most daily rations contained 2-3 fruit servings. Studies analyzing the diets of infants and young children in 2002 and 2008 [33,34,39] demonstrated that one out of five children aged 912 months did not consume any fruit, whereas in children older than 12 months, the recommended daily fruit intake was met in only 50\% of the cases. In a study by Yu [9], 38\% of young children did not consume any fruit.

In the examined diets, daily milk intake was equivalent to $55.4 \%$ of the reference value, which is a reason for concern. Insufficient consumption, especially of cow's milk, can lead to a decreased level of calcium. Milk and dairy are the main source of calcium, which stored in bones and teeth. Optimal peak bone mass and bone health later in life are favored by a sufficient calcium intake in infancy, childhood and adolescence. It is essential for prevents rickets and osteoporosis [40-42]. Lower milk consumption was accompanied by a higher intake of sweetened beverages and juice. In the work of Kay et al. [43], whole milk and $100 \%$ fruit juice were the most popular beverages among children aged 12-23.9 months. In older children (24-47.9 months), the consumption of fruit juice and sugar-sweetened beverages (SSB) was higher, and milk intake was lower [44].

\subsection{Consumption of Cow's Milk and Young-Child Formulas and Nutritional Requirements}

Modified milk is a dairy product fortified with minerals and vitamins, which can compensate for nutrient deficiencies that are sometimes observed in children aged 12 24 months during the transition to solid foods $[2,4,45]$. There is limited research on the contribution of milk to the diets of children younger than 2 years [10,46,47]. Young-child formulas could cater to the special dietary requirements of undernourished children, but the resulting intake of protein, sodium and vitamin A can exceed the recommended levels, whereas the intake of docosahexaenoic acid (DHA), arachidonic acid (ARA) and vitamin D can be insufficient [45]. 
The examined diets were deficient in high-quality fats. The consumption of saturated fatty acids (SFAs) tended to be excessive, whereas the intake of polyunsaturated fatty acids (PUFAs) tended to be insufficient regardless of the type of consumed milk. Similar observations were made in Australia, New Zealand [11], Germany [48] and the USA [49], where SFAs from dairy products were consumed in excess, whereas the dietary intake of PUFAs was low, even among children receiving fortified YCF. The results of dietary recalls differed significantly from nutritional models, which demonstrated that the replacement of $\mathrm{CM}$ with YCF would increase the consumption of healthy fats and reduce the intake of SFAs $[12,50]$.

Children in the second and third years of life are vulnerable to iron depletion, which may progress to iron-deficiency anemia (IDA) [51]. Iron depletion occurs in up to $30 \%$ of young children in developed countries $[52,53]$. In the present study, the mean daily intake of iron was determined at $7.45 \pm 1.9 \mathrm{mg}$, and it was equivalent to $106 \%$ of the reference value. Diets combining CM and YCFs met the demand for iron in 100\% and supplied adequate amounts of vitamin $C$, which improves iron absorption and availability. The main sources of iron were meat and cold cuts (heme iron) in the CM group, and fortified milk in the YCF group. Similar results were reported in research studies conducted in Sweden [54] and New Zealand [55], where dietary iron intake and the prevalence of anemia (iron deficiency) did not differ between children consuming CM and YCFs. Some studies postulated a negative correlation between the consumption of $\mathrm{CM}$ and dietary iron intake. Daily consumption of unmodified CM in excess of $450 \mathrm{~g}$ could increase the risk of iron deficiency [56,57].

The tolerable upper intake level (UL) of selected micronutrients, such as vitamin A, could be exceeded in children consuming fortified foods, in particular when the daily consumption of YCFs exceeds $600 \mathrm{~mL}[12,58]$. In the studied population, vitamin A intake exceeded reference levels two-fold in the YCF group, and it reached $132.8 \%$ of the guideline value in the CM group, where the main sources of vitamin A were butter, CM, eggs and carrots. In the PITNUTS study, vitamin A requirements were met by $96.6 \%$ of the children's diets [16]. The average dietary intake of vitamin A in children aged 13-24 months was insufficient only in the work of Sharma (2013) [59].

\subsection{Consumption of Young-Child Formulas and Cow's Milk vs. Children's Dietary Preferences}

The second year of life is a sensitive period for food acceptance and the development of eating habits. Cow's milk or YCFs are introduced to expand children's diets, but little is known about their influence on the formation of eating habits and nutrient intakes in 2-yearolds. Numerous researchers have expressed their concerns regarding YCFs as a substitute for a diverse diet, because children fed YCFs are more likely to become dependent on liquid food than those consuming regular homemade meals, and because YCFs may affect satiation in infants $[4,60]$. A recent position paper by ESPGHAN postulates that YCFs do not have to be administered routinely but could play a minor role in dietary strategies aiming to increase the intake of nutrients such as iron and vitamin D [4].

In the studied population, the introduction of YCFs significantly increased the consumption of sweetened dairy products, beverages and juice, and decreased the intake of plain fermented milks. There is evidence to suggest that the sweetness of YCFs causes babies to crave sweet taste. Sucrose-containing formulas were also found to boost appetite and promote hypersensitivity to sweetness [61-63]. Children consuming CM were less likely to drink sweetened beverages, their daily carbohydrate intake was nearly $20 \%$ lower and the percentage of total energy intake from carbohydrates was consistent with dietary guidelines. Contrary results were reported by Lovel who found that consumption of YCFs was associated with higher nutritional adequacy and an increased likelihood of meeting nutrient requirements. However, the impact of the family diet and YCFs on dietary diversity requires further evaluation [11]. 


\subsection{Strengths and Limitations}

The main strength of the present study was that the diets of children aged 1324 months were evaluated comprehensively by analyzing the daily intake of various food products as well as the overall quality of infant diets. Dietary and feeding patterns in toddlers (12 months to preschool age) have been insufficiently investigated in the Polish population. The division of the studied population into a group consuming YCFs and a group consuming $\mathrm{CM}$ supported the search for associations between milk type and the choice of other food products in a child's diet. This is an important consideration in view of excess intake of energy, juices and saturated fats, as well as the formation of desirable eating habits. The interviewed parents were eager to cooperate, and a high percentage of the respondents completed the questionnaire and kept food diaries. The respondents were also asked to state the reasons for choosing a given $\mathrm{YCF}$, which was yet another strength of the study.

The limitations of the study include the fact that the parents measured the children's dietary intakes with the use of household utensils and that foods which were not consumed during a meal were not taken into account in dietary recalls. Homemade meals were also problematic because their energy value was estimated based on meals that are most frequently served to Polish children. The study accounted for differences in the fat content of CM, whereas milk bought from a vending machine (which was listed in the dietary recalls of three children) was regarded as whole milk. The time required to complete the questionnaire was also a limitation. In the future, studies of the type could rely on telephone surveys to save the respondents' time and minimize direct contact between the respondents and the researchers, which is a particularly important consideration during the COVID-19 pandemic. The aim of the study was to investigate the eating habits of children aged 13-24 months and to identify undesirable behaviors that could negatively affect children's growth and development. The study did not attempt to identify the relationships between poor dietary habits and the risk of lifestyle diseases in later life, and further research is needed to explore this problem.

\section{Conclusions}

The daily food intake and the quality of the diets administered to children aged 13-24 months were evaluated and compared with the model food ration. The estimated number and size of portions involving products from all food groups were not consistent with nutritional guidelines. Excessive or inadequate consumption of selected products, relative to the model food ration, can increase the risk of lifestyle diseases in later life. Quantitative and qualitative modifications of the consumed diets could improve the nutritional status of the assessed children. The results of the study were also used to identify associations between the type of consumed milk, the nutritional value of children's diets and deficiency or excess of nutrients that are essential for healthy growth and development. It was found that milk type influenced children's eating habits and preference for sweet-tasting foods. The study also demonstrated that Polish parents and caregivers only have limited knowledge of nutritional guidelines for toddlers. Most respondents chose milk formulas based on price and availability, rather than nutritional content. The present findings can be used by pediatricians and dieticians to educate parents about the nutritional composition of YCFs and the benefits of reducing the amount of sugar in children's diets.

Author Contributions: M.K. was responsible for the conception and design of the main study. M.K. and I.J. were responsible for the design and data interpretation for this particular paper. J.K. was responsible for the data cleaning and statistical analysis for the main study and this particular paper. M.K. was responsible for data interpretation for this particular paper and writing the manuscript. M.K. and J.K. were responsible for data collection of the main study. M.K. and I.J. were responsible for revising the manuscript critically for important intellectual content. The manuscript was revised by all co-authors. All authors have read and agreed to the published version of the manuscript. 
Funding: The study was not financed by a research grant; the authors did research with the help of volunteers and with the funding allocated to science by the Ministry of Science and Higher Education.

Institutional Review Board Statement: Ethical review and approval were waived for this study, due to the survey research does not require the consent of the Bioethical committee for adult surveys in Poland, if the study is anonymous, voluntary, based on filling in questionnaire forms, does not collect personal data or laboratory tests and medical interviews.

Informed Consent Statement: Patient consent was waived due to this study being anonymous and not identifying the participants. All participants agreed to participate in the research anonymously by agreeing to complete questionnaires intended for research purposes.

Data Availability Statement: Due to ethical restrictions and participant confidentiality, data cannot be made publicly available. All data were collected in an anonymous way. The data that support the findings of this study are available from the authors upon reasonable request the corresponding author and with permission by main author.

Acknowledgments: Thanks are expressed to the participants for their contributions to the study, and the author would like to thank Joanna Kostecka-Jarecka, Renata Cioch, Anna Ciechańska and Dorota Niewegłowska for their help with data collection.

Conflicts of Interest: The authors declare no conflict of interest.

\section{References}

1. Marcinek, K.; Wójciak, R.W.; Krejpcio, Z. Assessment of the nutritional value daily food rations of children aged 1-4 years. Rocz. Państwowego Zakładu Hig. 2016, 67, 169-177.

2. Suthutvoravut, U.; Abiodun, P.O.; Chomtho, S.; Chongviriyaphan, N.; Cruchet, S.; Davies, P.S.; Fuchs, G.J.; Gopalan, S.; Van Goudoever, J.B.; Nel, E.D.L.R.; et al. Composition of Follow-Up Formula for Young Children Aged 12-36 Months: Recommendations of an International Expert Group Coordinated by the Nutrition Association of Thailand and the Early Nutrition Academy. Ann. Nutr. Metab. 2015, 67, 119-132. [CrossRef] [PubMed]

3. Lovell, A.L.; Davies, P.S.W.; Hill, R.J.; Milne, T.; Matsuyama, M.; Jiang, Y.; Chen, R.X.; A Wouldes, T.; Heath, A.-L.M.; Grant, C.C.; et al. Compared with Cow Milk, a Growing-Up Milk Increases Vitamin D and Iron Status in Healthy Children at 2 Years of Age: The Growing-Up Milk-Lite (GUMLi) Randomized Controlled Trial. J. Nutr. 2018, 148, 1570-1579. [CrossRef]

4. Hojsak, I.; Bronsky, J.; Campoy, C.; Domellöf, M.; Embleton, N.; Mis, N.F.; Hulst, J.; Indrio, F.; Lapillonne, A.; Mølgaard, C.; et al. Young Child Formula: A Position Paper by the ESPGHAN Committee on Nutrition. J. Pediatr. Gastroenterol. Nutr. 2018, 66, 177-185. [CrossRef] [PubMed]

5. Bundesinstitut Risikobewertung, 2014, Kindermilch-Abschlussbericht. Available online: https://www.bfr.bund.de (accessed on 16 March 2021).

6. Deming, D.M.; Afeiche, M.C.; Reidy, K.C.; Eldridge, A.L.; Villalpando-Carrión, S. Early feeding patterns among Mexican babies: Findings from the 2012 National Health and Nutrition Survey and implications for health and obesity prevention. BMC Nutr. 2015, 1, 321. [CrossRef]

7. Denney, L.; Afeiche, M.C.; Eldridge, A.L.; Villalpando-Carrión, S. Food Sources of Energy and Nutrients in Infants, Toddlers, and Young Children from the Mexican National Health and Nutrition Survey 2012. Nutrients 2017, 9, 494. [CrossRef]

8. Wang, H.; Denney, L.; Zheng, Y.; Vinyes-Pares, G.; Reidy, K.; Wang, P.; Zhang, Y. Food sources of energy and nutrients in the diets of infants and toddlers in urban areas of China, based on one 24-hour dietary recall. BMC Nutr. 2015, 1, 19. [CrossRef]

9. Yu, P.; Denney, L.; Zheng, Y.; Vinyes-Parés, G.; Reidy, K.C.; Eldridge, A.L.; Wang, P.; Zhang, Y. Food groups consumed by infants and toddlers in urban areas of China. Food Nutr. Res. 2016, 60, 30289. [CrossRef]

10. Walton, J.; Flynn, A. Nutritional adequacy of diets containing growing up milks or unfortified cow's milk in Irish children (aged 12-24 months). Food Nutr. Res. 2013, 57, 21836. [CrossRef]

11. Lovell, A.L.; Milne, T.; Jiang, Y.; Chen, R.X.; Grant, C.C.; Wall, C.R. Evaluation of the Effect of a Growing up Milk Lite vs. Cow's Milk on Diet Quality and Dietary Intakes in Early Childhood: The Growing up Milk Lite (GUMLi) Randomised Controlled Trial. Nutrients 2019, 11, 203. [CrossRef]

12. Eussen, S.R.; Pean, J.; Olivier, L.; Delaere, F.; Lluch, A. Theoretical Impact of Replacing Whole Cow's Milk by Young-Child Formula on Nutrient Intakes of UK Young Children: Results of a Simulation Study. Ann. Nutr. Metab. 2015, 67, $247-256$. [CrossRef] [PubMed]

13. Bundesinstitut fur Risikobewertung. Nährstoffgehalt von Kleinkindermilchgetr. 2011. Available online: https://www.bfr.bund. de (accessed on 16 March 2021). (In German).

14. Jong, J.K.-D.; De Vries, J.H.; Bleeker, S.E.; Jaddoe, V.W.V.; Hofman, A.; Raat, H.; Moll, H.A. Socio-demographic and lifestyle determinants of 'Western-like' and 'Health conscious' dietary patterns in toddlers. Br. J. Nutr. 2013, 109, 137-147. [CrossRef] [PubMed] 
15. Smithers, L.G.; Golley, R.K.; Brazionis, L.; Emmett, P.; Northstone, K.; Lynch, J.W. Dietary Patterns of Infants and Toddlers Are Associated with Nutrient Intakes. Nutrients 2012, 4, 935-948. [CrossRef] [PubMed]

16. Weker, H.; Barańska, M.; Riahi, A.; Strucińska, M.; Więch, M.; Rowicka, G.; Dylag, H.; Klemarczyk, W.; Bzikowska, A.; Socha, P. Nutrition of infants and young children in Poland-Pitnuts 2016. Dev. Period Med. 2017, 21, 13-28.

17. Weker, H.; Strucińska, M.; Barańska, M.; Więch, M.; Riahi, A. Modelowa racja pokarmowa dziecka w wieku poniemowlęcymuzasadnienie wdrożenia. Standardy Medyczne. Pediatria 2013, 10, 815-830. (In Polish)

18. Jezewska-Zychowicz, M.; Gawecki, J.; Wadolowska, L.; Czarnocinska, J.; Galinski, G.; Kollajtis-Dolowy, A.; Roszkowski, W.; Wawrzyniak, A.; Przybylowicz, K.; Stasiewicz, B.; et al. KomPAN ${ }^{\circledR}$ Dietary Habits and Nutrition Beliefs Questionnaire and the Manual for Developing of Nutritional Data, 2nd ed.; Dietary Habits and Nutrition Beliefs Questionnaire; Committee of Human Nutrition; Polish Academy of Sciences: Warsaw, Poland, November 2020.

19. Kowalkowska, J.; Wadolowska, L.; Hamulka, J.; Wojtas, N.; Czlapka-Matyasik, M.; Kozirok, W.; Bronkowska, M.; Sadowska, J.; Naliwajko, S.; Dziaduch, I.; et al. Reproducibility of a Short-Form, Multicomponent Dietary Questionnaire to Assess Food Frequency Consumption, Nutrition Knowledge, and Lifestyle (SF-FFQ4PolishChildren) in Polish Children and Adolescents. Nutrients 2019, 11, 2929. [CrossRef]

20. Kunachowicz, H.; Przygoda, B.; Iwanow, K.; Nadolna, I. Table of the Nutritional Value of Foods and Dishes, 4th ed.; Food and Nutrition Institute: Warsaw, Poland, 2017.

21. Jarosz, M.; Rychlik, E.; Stos, K.; Cherzewska, J. Nutrition Standards for the Population of Poland and Their Application; National Institute of Public Health-National Institute of Hygiene: Warsaw, Poland, 2020.

22. Choudhury, S.; Headey, D.D.; Masters, W.A. First foods: Diet quality among infants aged 6-23 months in 42 countries. Food Policy 2019, 88, 101762. [CrossRef]

23. Golley, R.K.; Smithers, L.G.; Mittinty, M.N.; Brazionis, L.; Emmett, P.; Northstone, K.; Campbell, K.; McNaughton, S.A.; Lynch, J.W. An Index Measuring Adherence to Complementary Feeding Guidelines Has Convergent Validity as a Measure of Infant Diet Quality. J. Nutr. 2012, 142, 901-908. [CrossRef]

24. World Health Organization. Guideline: Sugar Intake for Adults and Children; World Health Organization: Geneva, Switzerland, 2015.

25. Mis, N.F.; Braegger, C.; Bronsky, J.; Campoy, C.; Domellöf, M.; Embleton, N.D.; Hojsak, I.; Hulst, J.; Indrio, F.; Lapillonne, A.; et al. Sugar in Infants, Children and Adolescents: A Position Paper of the European Society for Paediatric Gastroenterology, Hepatology and Nutrition Committee on Nutrition. J. Pediatr. Gastroenterol. Nutr. 2017, 65, 681-696. [CrossRef]

26. Vos, M.B.; Kaar, J.L.; Welsh, J.A.; Van Horn, L.V.; Feig, D.; Anderson, C.A.M.; Patel, M.J.; Munos, J.C.; Krebs, N.F.; Xanthakos, S.A.; et al. Added Sugars and Cardiovascular Disease Risk in Children: A Scientific Statement from the American Heart Association. Circulation 2017, 135, e1017-e1034. [CrossRef]

27. World Health Organization. Commercial Foods for Infants and Young Children in the WHO European Region; WHO Regional Office for Europe: Copenhagen, Denmark, 2019.

28. Maalouf, J.; E Cogswell, M.; Bates, M.; Yuan, K.; Scanlon, K.S.; Pehrsson, P.; Gunn, J.P.; Merritt, R.K. Sodium, sugar, and fat content of complementary infant and toddler foods sold in the United States, 2015. Am. J. Clin. Nutr. 2017, 105, 1443-1452. [CrossRef] [PubMed]

29. Marinho, A.R.; Severo, M.; Correia, D.; Lobato, L.; Vilela, S.; Oliveira, A.; Ramos, E.; Torres, D.; Lopes, C. Total, added and free sugar intakes, dietary sources and determinants of consumption in Portugal: The National Food, Nutrition and Physical Activity Survey (IAN-AF 2015-2016). Public Health Nutr. 2019, 23, 869-881. [CrossRef] [PubMed]

30. Yuan, W.L.; Nicklaus, S.; Lioret, S.; Lange, C.; Forhan, A.; Heude, B.; Charles, M.A.; De Lauzon-Guillain, B. Early factors related to carbohydrate and fat intake at 8 and 12 months: Results from the EDEN mother-child cohort. Eur. J. Clin. Nutr. 2017, 71, 219-226. [CrossRef] [PubMed]

31. Masztalerz-Kozubek, D.; Zielinska, M.; Rust, P.; Majchrzak, D.; Hamulka, J. The Use of Added Salt and Sugar in the Diet of Polish and Austrian Toddlers. Associated Factors and Dietary Patterns, Feeding and Maternal Practices. Int. J. Environ. Res. Public Health 2020, 17, 5025. [CrossRef]

32. Bortolini, G.A.; Gubert, M.B.; Santos, L.M.P. Consumo alimentar entre crianças brasileiras com idade de 6 a 59 meses [Food consumption Brazilian children by 6 to 59 months of age]. Cad. Saúde Pública 2012, 28, 1759-1771. [CrossRef]

33. Siega-Riz, A.M.; Deming, D.M.; Reidy, K.C.; Fox, M.K.; Condon, E.; Briefel, R.R. Food Consumption Patterns of Infants and Toddlers: Where Are We Now? J. Am. Diet. Assoc. 2010, 110, S38-S51. [CrossRef]

34. Roess, A.A.; Jacquier, E.F.; Catellier, D.J.; Carvalho, R.; Lutes, A.C.; Anater, A.S.; Dietz, W.H. Food Consumption Patterns of Infants and Toddlers: Findings from the Feeding Infants and Toddlers Study (FITS) 2016. J. Nutr. 2018, 148, 1525S-1535S. [CrossRef]

35. Welker, E.B.; Jacquier, E.F.; Catellier, D.J.; Anater, A.S.; Story, M.T. Room for Improvement Remains in Food Consumption Patterns of Young Children Aged 2-4 Years. J. Nutr. 2018, 148, 1536S-1546S. [CrossRef] [PubMed]

36. Deming, D.M.; Briefel, R.R.; Reidy, K.C. Infant Feeding Practices and Food Consumption Patterns of Children Participating in WIC. J. Nutr. Educ. Behav. 2014, 46, S29-S37. [CrossRef] [PubMed]

37. Bawaked, R.A.; Schröder, H.; Ribas-Barba, L.; Izquierdo-Pulido, M.; Pérez-Rodrigo, C.; Fíto, M.; Serra-Majem, L. Association of diet quality with dietary inflammatory potential in youth. Food Nutr. Res. 2017, 61, 1328961. [CrossRef]

38. Patel, S.; Murray, C.S.; Woodcock, A.; Simpson, A.; Custovic, A. Dietary antioxidant intake, allergic sensitization and allergic diseases in young children. Allergy 2009, 64, 1766-1772. [CrossRef] 
39. Ziegler, P.; Hanson, C.; Ponza, M.; Novak, T.; Hendricks, K. Feeding Infants and Toddlers Study: Meal and Snack Intakes of Hispanic and Non-Hispanic Infants and Toddlers. J. Am. Diet. Assoc. 2006, 106, 107-123. [CrossRef]

40. Farré Rovira, R. La leche y los productos lácteos: fuentes dietéticas de calcio [Milk and milk products: food sources of calcium]. Nutr. Hosp. 2015, 31, 1-9. [CrossRef]

41. Vogel, K.A.; Martin, B.R.; McCabe, L.D.; Peacock, M.; Warden, S.J.; McCabe, G.P.; Weaver, C.M. The effect of dairy intake on bone mass and body composition in early pubertal girls and boys: A randomized controlled trial. Am. J. Clin. Nutr. 2017, 105, 1214-1229. [CrossRef] [PubMed]

42. Pampaloni, B.; Cianferotti, L.; Gronchi, G.; Bartolini, E.; Fabbri, S.; Tanini, A.; Brandi, M.L. Growing Strong and Healthy with Mister Bone: An Educational Program to Have Strong Bones Later in Life. Nutrients 2015, 7, 9985-9998. [CrossRef] [PubMed]

43. Kay, M.C.; Welker, E.B.; Jacquier, E.F.; Story, M.T. Beverage Consumption Patterns among Infants and Young Children (0-47.9 Months): Data from the Feeding Infants and Toddlers Study, 2016. Nutrients 2018, 10, 825. [CrossRef] [PubMed]

44. Heyman, M.B.; Abrams, S.A. Fruit Juice in Infants, Children, and Adolescents: Current Recommendations. Pediatrics 2017, 139, e20170967. [CrossRef]

45. Chouraqui, J.-P.; Turck, D.; Tavoularis, G.; Ferry, C.; Dupont, C. The Role of Young Child Formula in Ensuring a Balanced Diet in Young Children (1-3 Years Old). Nutrients 2019, 11, 2213. [CrossRef] [PubMed]

46. Ghisolfi, J.; Fantino, M.; Turck, D.; De Courcy, G.P.; Vidailhet, M. Nutrient intakes of children aged 1-2 years as a function of milk consumption, cows' milk or growing-up milk. Public Health Nutr. 2013, 16, 524-534. [CrossRef]

47. Byrne, R.; Magarey, A.; Daniels, L. Food and beverage intake in Australian children aged 12-16 months participating in the NOURISH and SAIDI studies. Aust. N. Z. J. Public Health 2014, 38, 326-331. [CrossRef]

48. Hilbig, A.; Drossard, C.; Kersting, M.; Alexy, U. Nutrient Adequacy and Associated Factors in a Nationwide Sample of German Toddlers. J. Pediatr. Gastroenterol. Nutr. 2015, 61, 130-137. [CrossRef]

49. Butte, N.F.; Fox, M.K.; Briefel, R.R.; Siega-Riz, A.M.; Dwyer, J.; Deming, D.M.; Reidy, K.C. Nutrient Intakes of US Infants, Toddlers, and Preschoolers Meet or Exceed Dietary Reference Intakes. J. Am. Diet. Assoc. 2010, 110, S27-S37. [CrossRef]

50. Vandenplas, Y.Y.; De Ronne, N.N.; Van De Sompel, A.A.; Huysentruyt, K.; Robert, M.M.; Rigo, J.J.; Scheers, I.I.; Brasseur, D.; Goyens, P. A Belgian consensus-statement on growing-up milks for children 12-36 months old. Eur. J. Nucl. Med. Mol. Imaging 2014, 173, 1365-1371. [CrossRef] [PubMed]

51. Sutcliffe, T.L.; Khambalia, A.; Westergard, S.; Jacobson, S.; Peer, M.; Parkin, P.C. Iron Depletion Is Associated with Daytime Bottle-feeding in the Second and Third Years of Life. Arch. Pediatr. Adolesc. Med. 2006, 160, 1114-1120. [CrossRef] [PubMed]

52. Booth, I.W.; Aukett, M.A. Iron deficiency anaemia in infancy and early childhood. Arch. Dis. Child. 1997, 76, 549-554. [CrossRef] [PubMed]

53. Mattiello, V.; Schmugge, M.; Hengartner, H.; Von Der Weid, N.; Renella, R. Diagnosis and management of iron deficiency in children with or without anemia: Consensus recommendations of the SPOG Pediatric Hematology Working Group. Eur. J. Pediatr. 2020, 179, 527-545. [CrossRef]

54. Virtanen, M.A.; E Svahn, C.J.; Viinikka, L.U.; Räihä, N.C.R.; A Siimes, M.; Axelsson, I.E.M. Iron-fortified and unfortified cow's milk: Effects on iron intakes and iron status in young children. Acta Paediatr. 2001, 90, 724-731. [CrossRef] [PubMed]

55. Szymlek-Gay, E.A.; Ferguson, E.L.; Heath, A.-L.M.; Gray, A.R.; Gibson, R.S. Food-based strategies improve iron status in toddlers: A randomized controlled trial. Am. J. Clin. Nutr. 2009, 90, 1541-1551. [CrossRef] [PubMed]

56. Gunnarsson, B.S.; Thorsdottir, I.; Palsson, G. Iron status in 2-year-old Icelandic children and associations with dietary intake and growth. Eur. J. Clin. Nutr. 2004, 58, 901-906. [CrossRef]

57. Ziegler, E.E. Consumption of cow's milk as a cause of iron deficiency in infants and toddlers. Nutr. Rev. 2011, 69, S37-S42. [CrossRef]

58. Kloosterman, J.; Fransen, H.P.; De Stoppelaar, J.; Verhagen, H.; Rompelberg, C. Safe addition of vitamins and minerals to foods: Setting maximum levels for fortification in the Netherlands. Eur. J. Nutr. 2007, 46, 220-229. [CrossRef] [PubMed]

59. Sharma, S.; Kolahdooz, F.; Butler, L.; Budd, N.; Rushovich, B.; Mukhina, G.L.; Gittelsohn, J.; Caballero, B. Assessing dietary intake among infants and toddlers 0-24 months of age in Baltimore, Maryland, USA. Nutr. J. 2013, 12, 52. [CrossRef] [PubMed]

60. European Commission. Directorate-General for Health and Food Safety 2016 Young Child Formulae: Background Information; European Commission: Brussels, Belgium; Available online: https:/ / eur-lex.europa.eu/legal-content/EN/TXT/PDF/?uri=CELEX:5201 6DC0169\&from=LT (accessed on 5 March 2021).

61. Baby Formula Expert, Baby Formula Carbs-Not All Created Equal. 2017. Available online: https://babyformulaexpert.com/ baby-formula-carbs / (accessed on 10 March 2021).

62. Terrero, N. How Much Sugar is in Brand-Name Baby Formula? Parenting and Family. 2017. Available online: http:/ / nbclatino. com/2012/02/22/18091566837/ (accessed on 17 March 2021).

63. Caplan, L.S.; Erwin, K. Does Sugar in Infant Formula Cause Early Childhood Caries? Arch. Paediatr. Dev. Pathol. 2017, 1, 1014. 